OPEN ACCESS

Edited by:

Rosario Paolo Mauro,

University of Catania, Italy

Reviewed by:

Libo Xing,

Northwest A and F University, China

Gennaro Fazio,

Plant Genetic Resources Unit (USDA ARS), United States

*Correspondence: Darius Kviklys

d.kviklys@/sdi.lt

Specialty section: This article was submitted to Crop and Product Physiology, a section of the journal

Frontiers in Plant Science

Received: 22 April 2020

Accepted: 24 July 2020

Published: 07 August 2020

Citation:

Kviklys D and Samuoliené G (2020) Relationships Among the Rootstock,

Crop Load, and Sugar Hormone

Signaling of Apple Tree, and Their Effects on Biennial Bearing.

Front. Plant Sci. 11:1213.

doi: 10.3389/fpls.2020.01213

\section{Relationships Among the Rootstock, Crop Load, and Sugar Hormone Signaling of Apple Tree, and Their Effects on Biennial Bearing}

\author{
Darius Kviklys $^{1,2^{*}}$ and Giedrè Samuoliené ${ }^{1}$ \\ 1 Lithuanian Research Centre for Agriculture and Forestry, Institute of Horticulture, Babtai, Lithuania, ${ }^{2}$ Department of \\ Horticulture, Norwegian Institute of Bioeconomy Research-NIBIO Ullensvang, Lofthus, Norway
}

Adjustable crop load primarily involves bud manipulation, and usually switches from vegetative to reproductive buds. While this switch is not fully understood, it is still controlled by the ratio of hormones, which promote or inhibit bud formation. To determine the reasons for biennial bearing, the effect of apple rootstock, scion cultivar, crop load, as well as metabolic changes of endogenous phytohormones [zeatin, jasmonic acid, indole-3 acetic acid (IAA), abscisic acid (ABA), and gibberellins 1, 3, and 7 (GAs)], and soluble sugars (glucose, fructose, and sorbitol) were evaluated, and their connections with return bloom and yield of apple tree buds were analyzed. Cultivars "Ligol" and "Auksis" were tested on five rootstocks contrasting in induced vigor: semi-dwarfing M.26; dwarfing M.9, B.396, and P 67; and super-dwarfing P 22. Crop load levels were adjusted before flowering, leaving 75, 113, and 150 fruits per tree. Principal component analysis (PCA) scatter plot of the metabolic response of phytohormones and sugars indicated that the effect of the semi-dwarfing M.26 rootstock was significantly different from that of the dwarfing M.9 and P 67, as well as the super-dwarfing P 22 rootstocks in both varieties. The most intensive crop load (150 fruits per tree) produced a significantly different response compared to less intensive crop loads (113 and 75$)$ in both varieties. In contrast to soluble sugar accumulation, increased crop load resulted in an increased accumulation of phytohormones, except for ABA. Dwarfing rootstocks M.9, B.396, and P 67, as well as super-dwarf $P 22$ produced an altered accumulation of promoter phytohormones, while the more vigorous semi-dwarfing M.26 rootstock induced a higher content of glucose and inhibitory phytohormones, by increasing content of IAA, $A B A$, and GAs. The most significant decrease in return bloom resulted from the highest crop load in "Auksis" grafted on M.9 and P 22 rootstocks. Average difference in flower number between crop loads of 75 and 150 fruits per tree in "Ligol" was 68\%, while this difference reached 90\% for P 22, and 75\% for M.9 and M.26 rootstocks. Return bloom was dependent on the previous year's crop load, cultivar, and rootstock.

Keywords: dwarfing rootstocks, Malus $\times$ domestica Borkh., phytohormones, return bloom, sugars 


\section{INTRODUCTION}

Apple rootstocks are categorized according to tree vigor, i.e., dwarfing, semi-dwarfing, semi-vigorous, and vigorous. As the production of dwarfing rootstocks has greatly increased the yield efficiency, fruit size, and quality of the commercial apple orchard, focus on rootstock-scion interactions have become increasingly important. Studies performed in Lithuania investigating the effect of rootstock on fruit quality, particularly with respect to bioactive compound accumulation, revealed that a significantly higher phenol content was found in "Ligol" fruits on P 61 and P 22 rootstocks, compared to "Auksis" fruits produced on P 67 rootstock (Kviklys et al., 2014; Kviklys et al., 2017). Rootstockcultivar interaction was found to be significant in evaluating the effect of rootstock on apple tree growth habit, or root architecture (Tworkoski and Miller, 2007; Harrison et al., 2016; Lordan et al., 2017).

The effect of different rootstocks on apple tree productivity was established in our rootstock trials performed in three countries. M.9 rootstock was the most productive under Lithuanian climate conditions; Pure 1, P 60, and B.9 were most productive in Latvia and Bulboga, while B.146 and M.26 were the most productive in Estonia (Kviklys et al., 2012). Significant rootstock behavior was established under varying growth conditions in a separate international trial, where the most productive trees were found on B.396 and M.9 rootstocks in Lithuania, on M.26 in Poland, on P 67 and P 22 in Latvia, and on M.26 in Estonia (Kviklys et al., 2013). Rootstock-scion or rootstock-location interactions were observed in NC-140 multi-location trials in the United States of America (Autio, 2001; Hirst et al., 2001), as well as in studies performed in other countries (Denardi et al., 2018).

Rootstock-cultivar interaction was found to be significant in evaluating the effect of rootstock on apple bearing stability (Kviklys et al., 2016). Alternate bearing is widespread in most of cultivated apple cultivars and causes serious economic losses for apple industry.

Plant vegetative and reproductive development is regulated by endogenous phytohormones. Phytohormones are translocated to the sites of action as signal molecules which affect tissue differentiation, and perform both above and below the grafted interface (Baron et al., 2019). Auxins and cytokinins (CKs) act antagonistically to regulate root and shoot growth, as well as the outgrowth of axillary meristems, while playing a role in each other's synthesis and transport (Müller and Leyser, 2011). In contrast to auxins, CKs are produced in the root and translocated to the shoot, where they control important developmental processes such as shoot growth and productivity (Aloni et al., 2010). A decrease in the basipetal flow of indole-3 acetic acid (IAA) from the shoot stimulates the synthesis and export of CKs from the root. It was demonstrated that in contrast to non-grafted plants, grafting disturbed the auxin/CK balance (Sorce et al., 2002). Several studies have shown that, compared to vigorous rootstocks, dwarfing rootstocks (e.g., M.9) reduce the basipetal transport of IAA to the root, thereby reducing the amount of root-produced CK and gibberellin (GA) transported to the scion (Michalczuk, 2002; Van Hooijdonk et al., 2010), while others have shown an inverse relationship between the rate of IAA diffusion and the CK concentration in the xylem (Van Hooijdonk et al., 2011). Although GAs are well-known for promoting rosette flowering in herbaceous plants, they are commonly known to repress flowering in apple. A simple explanation for this repression is that GA induces the expression of MdTFL1-1 which acts as a flowering repressor in apple (Peace et al., 2019). In addition, GAs are leading phytohormones that modulate apical meristem differentiation by downregulating their levels at the induction of dormancy, followed by upregulation during dormancy release or bud burst (Liu and Sherif, 2019). Abscisic acid (ABA) coordinates root and shoot growth in plants (Sharp and LeNoble, 2002), regulates tolerance responses to a number of stress factors, and is one of the main determinants responsible for triggering the dwarfing process in higher species (Tworkoski and Fazio, 2015). ABA homeostasis in plants is essential for normal growth and development processes, in which buds are both the target site for ABA activity, and the principal location for ABA metabolism and catabolism (Liu and Sherif, 2019). Multiple physiological and transcriptomic studies have indeed proposed a central role for $\mathrm{ABA}$ in the repression of bud activity during early apical meristem differentiation, whereby $\mathrm{ABA}$ would function as a signal in response to short autumn days and decreasing temperatures in order to induce dormancy ( $\mathrm{Li}$ et al., 2018; Tylewicz et al., 2018; Liu and Sherif, 2019).

Dwarfing apple rootstocks produced higher ABA concentrations compared to vigorous apple rootstocks. While there is no consensus, it has been suggested that ABA may support the role of GA in vigorous rootstocks, as opposed to dwarfing rootstocks (Baron et al., 2019). The proposed role of GAs in the dwarfing response (Van Hooijdonk et al., 2010) has been unclear since Van Hooijdonk et al. (2011) reported that concentrations of $\mathrm{GA}_{19}$ were similar in the xylem sap collected throughout the growing season from scions grafted on to M.9 or MM.106 rootstocks, and suggested that $\mathrm{GA}_{19}$ may be a precursor of bioactive $\mathrm{GA}_{1}$, required for shoot extension growth. Lower $\left(\mathrm{GA}_{19}\right)$ levels were found in root and xylem exudates of scion cultivars grafted on dwarfing rootstock, compared to those grafted on semi-vigorous rootstocks (Tworkoski and Fazio, 2016). Thus, the effects of hormone signaling may vary at different stages of establishing communication in the graft union. Else et al. (2018) suggested that the manner in which rootstocks imparted their control over grafted scions was complex and included a "filtering effect" of the graft union at significantly low flow rates, an augmentation of xylem sap constituents via passage through the union at increased flow rates, and an altered synthesis or metabolism of key rootstocksourced hormone signals.

One of the main causes of biennial bearing in apple trees is the inhibition of flower initiation by adjacent developing fruits. The distance between flower clusters in 1 year has long been known to influence the development of floral buds in the following year (Nichols et al., 2011). This localized inhibition may depend on a critical ratio of inhibitor and promoter hormones that inhibits the flowering of apical meristems (Pellerin et al., 2012), or may be 
a result of carbon limitation and/or hormonal inhibition of floral initiation by nearby seeds (Dennis, 2000). Inhibition of floral initiation by endogenous GAs (possibly $\mathrm{GA}_{1}, \mathrm{GA}_{4}$, and iso- $\mathrm{GA}_{7}$ ) produced by seeds was confirmed in heavily cropped "Fuji" trees (Kittikorn et al., 2010) and "Golden Delicious" (Ramírrez et al., 2004). GAs and jasmonic acid (JA) act antagonistically, with JA detected at high concentrations in apple trees when GA concentrations are low, suggesting its key role in floral initiation (Kittikorn et al., 2010).

Numerous studies have demonstrated a clear connection between sugar-sensing pathways and phytohormone metabolism and signaling (Eveland and Jackson, 2012; Ljung et al., 2015; Foster et al., 2017). Hormonal signals may regulate rootstockmediated vigor by modulating gene expression in the scion, including sink activity (Albacete et al., 2015). Invigorating rootstocks upregulate genes involved in carbohydrate metabolism and sugar transport in the scion apical meristem (Foster et al., 2017). Increased sink strength of the primary form of transported carbon in the shoot apex show the best correlation between sorbitol dehydrogenase and plant size in grafted apple trees (Jensen et al., 2010). In addition, sorbitol dehydrogenase activity is modulated by phytohormonal changes, and is negatively (by ABA) and positively (by CKs) correlated with drought stress-induced hormonal changes (Li and Li, 2007). Cheng et al. (2002) suggested that glucose increases ABA biosynthetic gene expression. Glucose and auxin act synergistically in plant development (Procko et al., 2014) and promote polar auxin transport (Hornitschek et al., 2012). Glucose and CKs also share several transcriptional targets. Moore et al. (2003) demonstrated that a mutant defective in glucose sensing was hypersensitive to $\mathrm{CK}$ and insensitive to auxin. There is also evidence of metabolite dynamics, especially of raffinose family oligosaccharides, being correlated with many cold-related gene expression changes during transition to flowering (Peace et al., 2019).

Although it is unclear whether the reduced sugar concentrations in dwarfing rootstocks are the cause or result of altered hormone levels or signaling, these metabolic changes have a significant effect on grafted apple tree growth and development. In order to identify the physiological processes and regulatory networks involved with rootstock-induced dwarfing, we compared the metabolic changes of phytohormones and soluble sugars in apical meristems from dwarfing and vigorous rootstocks. The aim of the present study was to evaluate interactions between apple rootstocks, scions and different crop load levels that could influence return bloom and identify the differences in physiological status between dwarfing and vigorous rootstocks.

\section{MATERIALS AND METHODS}

\section{Growing Conditions}

Experiments investigating the effect of apple rootstock, scion cultivar, and crop load on apple return bloom were performed in Lithuania $\left(55^{\circ} 60^{\prime} \mathrm{N}, 23^{\circ} 48^{\prime} \mathrm{E}\right)$ in 2014-2016. Apple cultivars "Ligol" (Poland) and "“"Auksis" (Lithuania) on five rootstocks with contrasting induced vigor were tested: semi-dwarf M.26; dwarf M.9, B.396, and P 67; and super-dwarf P 22. The orchard was planted in 2005 , at $4 \mathrm{~m} \times 1.5 \mathrm{~m}$ intervals. Trees were trained as slender spindles. Pest and disease management was carried out according to the rules of integrated plant protection (Valiuškaite et al., 2017).

Thinning of flower clusters and fruitlets was carried out before flowering at the pink bud stage and corrected after the June drop by adjusting three crop load levels: 75, 113, and 150 fruits per tree. Taking the average fruit weight into account, the expected yield at these crop levels was 21,32 , and $43 \mathrm{t} \mathrm{ha}^{-1}$ for "Auksis", and 27, 41, and $54 \mathrm{t} \mathrm{ha}^{-1}$ for "Ligol", respectively.

Return bloom was evaluated a year following crop load adjustment, at the balloon stage of flowering, by counting all the flower clusters per tree.

Bud development in September and November was defined according to Foster et al. (2003). Thirty buds from each grafting and crop load treatment were evaluated.

\section{Determination of Phytohormones}

Approximately $0.5 \mathrm{~g}$ of fresh plant tissue (90-120 buds per treatment) was ground with liquid $\mathrm{N}_{2}$ and extracted with $5 \mathrm{ml}$ of cold $50 \%(\mathrm{v} / \mathrm{v})$ acetonitrile. An internal standard solution mixture containing isotope-labeled phytohormones $(200 \mathrm{pmol}$ IAA, 40 pmol GA $1, \mathrm{GA}_{4}$, and $\mathrm{GA}_{7}, 100 \mathrm{pmol} \mathrm{ABA}$, and $100 \mathrm{pmol}$ zeatin) was added to the samples. Samples were purified using Chromabond HLB SPE cartridges $(3 \mathrm{ml}, 60 \mathrm{mg}$, MachereyNagel). Briefly, cartridges were conditioned with $2 \mathrm{ml} \mathrm{MeOH}$ and $2 \mathrm{ml} \mathrm{H}_{2} \mathrm{O}$. Samples were applied to the cartridges, and the pass-through was collected. Sample elution was carried out with $30 \%$ acetonitrile, and each eluted sample was collected together with the pass-through. Samples were dried in a vacuum concentrator and dissolved in $50 \mu \mathrm{l}$ of $30 \%(\mathrm{v} / \mathrm{v})$ acetonitrile.

Phytohormone analysis was performed in buds collected in mid-September, according to the procedure described by Šimura et al. (2018) with modifications, using ultra performance liquid chromatography (UPLC; Waters) combined with mass spectrometry (LC-MS/MS). Separation of phytohormones (GAs: $\mathrm{GA}_{1}, \mathrm{GA}_{4}$, and $\mathrm{GA}_{7}$, IAA, JA, ABA, and zeatin) was performed using an Acquity BEH C18 column $(1.0 \times 150 \mathrm{~mm}$; Waters). The mobile phase was A: water [with $0.02 \%$ (v/v) acetic acid], and B: acetonitrile with $0.02 \%(\mathrm{v} / \mathrm{v})$ acetic acid, at a flow rate of $0.1 \mathrm{ml} \mathrm{min}^{-1}$. Gradient was maintained at $5 \% \mathrm{~B}$ for $3 \mathrm{~min}$, raised to $40 \% \mathrm{~B}$ in $12 \mathrm{~min}$, raised to $90 \% \mathrm{~B}$ in $1 \mathrm{~min}$, maintained at $90 \% \mathrm{~B}$ for $1.5 \mathrm{~min}$, and equilibrated at $5 \% \mathrm{~B}$ for $4 \mathrm{~min}$, before starting the next injection. Hormones were detected with the Bruker Ultra HTC ion trap mass spectrometer in negative mode, using multiple reaction monitoring (MRM).

\section{Determination of Sugars}

Approximately $0.5 \mathrm{~g}$ of fresh plant tissue (90-120 buds per treatment) was ground and diluted with deionized $\mathrm{H}_{2} \mathrm{O}$. The extraction process was carried out for $4 \mathrm{~h}$ at $20^{\circ} \mathrm{C}$ with mixing. Samples were centrifuged at $14,000 \times g$ for $15 \mathrm{~min}$. A clean-up step was performed prior to the chromatographic analysis. Briefly, $1 \mathrm{ml}$ of supernatant was mixed with $1 \mathrm{ml}$ of $0.01 \%$ 
$(\mathrm{w} / \mathrm{v})$ ammonium acetate in acetonitrile, and incubated for $30 \mathrm{~min}$ at $+4{ }^{\circ} \mathrm{C}$. The samples were centrifuged at $14,000 \times g$ for $15 \mathrm{~min}$ and filtered through a $0.22-\mu \mathrm{m}$ PTFE syringe filter (VWR International, USA). The analyses were performed using a Shimadzu HPLC instrument (Japan) equipped with an evaporative light scattering detector (ELSD). The separation of fructose, glucose, and sucrose was performed using a Shodex VG-50 4D HPLC column with deionized water (mobile phase A) and acetonitrile (mobile phase $\mathrm{B}$ ) gradient. The gradient was maintained at $88 \%$ B for $13 \mathrm{~min}$, changed linearly to $70 \% \mathrm{~B}$ in 9 min, maintained at $70 \%$ B for $1 \mathrm{~min}$, raised back to $88 \%$ B in $2 \mathrm{~min}$, and the column was equilibrated to $88 \% \mathrm{~B}$ for $5 \mathrm{~min}$. The



\section{Statistical Analysis}

The experiment was carried out in a randomized complete block design with three replicates and one single tree in each plot. Data was processed using the XLStat software. Analysis of variance (ANOVA) was carried out along with the post-hoc Tukey's HSD test for statistical analyses. Differences were considered to be significant at $\mathrm{p}<0.05$. Multivariate principal component analysis (PCA) was also performed. The agglomerative hierarchical cluster (AHC) analysis was used to generate similarity cluster diagrams based on the rootstock, crop load and metabolites similarity, and variables similarity.

\section{RESULTS}

Evaluation of the effect of rootstock on apple return bloom showed that the average highest number of flower clusters for both tested cultivars was recorded in trees on M.9 and P 67 rootstocks (Table 1). "Auksis" trees on M.9, and "Ligol” trees on P 67 and M.9 rootstocks produced a significantly higher number of flower clusters. A significantly lower return bloom was recorded for "Auksis" on B.396 rootstock, and for "Ligol" on P 22 rootstock.

Evaluation of the effect of crop load on apple return bloom showed that both cultivars responded in the same way, i.e., the higher the crop load established in the previous year, the lower the recorded return bloom. Significant differences were established among all crop load levels. However, suppression of return bloom was different for both cultivars when comparing the lowest and highest crop levels. The return bloom of "Ligol" at a crop load of 150 fruits per tree was lower by $68 \%$, compared to that obtained at a crop load of 75 fruits per tree, while return bloom of "Auksis" was lower only by $24 \%$.

Evaluation of the effect of rootstock and crop load interactions on cultivar response produced varying results. Return bloom of "Ligol" on all rootstocks significantly depended on crop load. Only crop load levels of 113 and 150 fruits per tree, established on B.396 rootstock, did not significantly differ. Differences between crop load effect on return bloom of "Auksis" were less pronounced. Significant differences were recorded by comparing only the highest and lowest crop load levels, with no differences found between
TABLE 1 | The effect of rootstock and crop load interaction on the return bloom of "Ligol" and "Auksis" apple trees (number of flower clusters tree ${ }^{-1}$ ).

\begin{tabular}{|c|c|c|c|}
\hline Treatment & “Ligol” & “Auksis" & Average \\
\hline M.26 (75) & $153.0 \mathrm{a}^{\star}$ & 142.3 bc & $147.7 \mathrm{a}$ \\
\hline M.26 (113) & $34.7 \mathrm{f}$ & 117.3 cde & $76.0 \mathrm{f}$ \\
\hline M.26 (150) & $16.3 \mathrm{~g}$ & 109.3 de & $62.8 \mathrm{~h}$ \\
\hline M.9 (75) & $101.3 \mathrm{c}$ & $176.0 \mathrm{a}$ & $138.7 \mathrm{ab}$ \\
\hline M.9 (113) & 125.3 b & 120.7 cde & $123.0 \mathrm{~cd}$ \\
\hline M.9 (150) & $23.7 \mathrm{fg}$ & 108.7 de & $66.2 \mathrm{gh}$ \\
\hline B.396 (75) & $92.7 \mathrm{~cd}$ & 98.7 e & 95.7 de \\
\hline B.396 (113) & $62.0 \mathrm{e}$ & $98.7 \mathrm{e}$ & $80.3 \mathrm{f}$ \\
\hline B.396 (150) & 58.7 e & $93.7 \mathrm{e}$ & $76.2 \mathrm{fg}$ \\
\hline P 67 (75) & $130.0 \mathrm{~b}$ & 131.0 bc & $130.5 \mathrm{bc}$ \\
\hline P 67 (113) & $82.0 \mathrm{~d}$ & $124.3 \mathrm{~cd}$ & 103.2 de \\
\hline P 67 (150) & $60.0 \mathrm{e}$ & 116.3 de & 88.2 ef \\
\hline P 22 (75) & $86.3 \mathrm{~cd}$ & $151.0 \mathrm{ab}$ & $118.7 \mathrm{~cd}$ \\
\hline P 22 (113) & 55.7 e & 116.3 cde & 86.0 ef \\
\hline P 22 (150) & $21.7 \mathrm{fg}$ & 102.7 de & $62.2 \mathrm{~h}$ \\
\hline \multicolumn{4}{|c|}{ Effect of rootstock } \\
\hline M.26 & $68.0 \mathrm{~b}$ & $123.0 \mathrm{~b}$ & 95.5 b \\
\hline M.9 & $83.4 \mathrm{a}$ & $135.1 \mathrm{a}$ & $109.3 \mathrm{a}$ \\
\hline B.396 & $71.1 \mathrm{~b}$ & $97.0 \mathrm{c}$ & $84.1 \mathrm{c}$ \\
\hline P 67 & $90.7 \mathrm{a}$ & $123.9 b$ & $107.3 \mathrm{a}$ \\
\hline P 22 & $54.6 \mathrm{c}$ & $123.3 b$ & 88.9 bc \\
\hline \multicolumn{4}{|c|}{ Effect of crop load } \\
\hline 75 & $112.7 \mathrm{a}$ & $139.8 \mathrm{a}$ & $126.2 \mathrm{a}$ \\
\hline 113 & $71.9 \mathrm{~b}$ & $115.5 b$ & 93.7 b \\
\hline 150 & $36.1 \mathrm{c}$ & $106.1 \mathrm{c}$ & $71.1 \mathrm{C}$ \\
\hline
\end{tabular}

*The different letters on the same column indicate significant differences between treatments, rootstock and crop load separately. The analysis was conducted with all data resulting from 9 trees of "Ligol" and "Auksis" apple trees grafted on M.26, M.9, B.396, $P 67$, and $P$ 22, with crop-load adjusted to 75,113 , and 150 fruits per tree. The data were processed using analysis of variance (ANOVA), the Turkey (HSD) multiple range test at the confidence level $p=0.05$.

adjacent crop load levels on almost all rootstocks, and no differences detected among all the levels on B.396 rootstock.

Generative bud development in September and November was defined for both varieties (Table 2). P 22 rootstock produced the slowest bud development for both varieties. In September, $85 \%$ and $75 \%$ of the buds developed until stage 4 (with formation of terminal floral meristems) in "Ligol" and "Auksis" apple trees respectively, while the remainder were at stage 5. Further development of terminal floral meristems with bractlets and sepals (stage 5) reached $75 \%$ and $100 \%$ in "Ligol" and "Auksis" apple trees, respectively, in November.

TABLE 2 | Bud development (\%) of "Ligol" and "Auksis" apple trees in autumn.

\begin{tabular}{|c|c|c|c|c|c|c|}
\hline \multirow[t]{3}{*}{ Rootstocks } & \multicolumn{3}{|c|}{ “Ligol” } & \multicolumn{3}{|c|}{ "Auksis" } \\
\hline & \multirow{2}{*}{$\frac{\text { September }}{\text { Stage } 4}$} & \multicolumn{2}{|c|}{ November } & \multirow{2}{*}{$\frac{\text { September }}{\text { Stage } 4}$} & \multicolumn{2}{|c|}{ November } \\
\hline & & $\begin{array}{c}\text { Stage } \\
5\end{array}$ & $\begin{array}{c}\text { Stage } \\
5\end{array}$ & & $\begin{array}{c}\text { Stage } \\
5\end{array}$ & $\begin{array}{c}\text { Stage } \\
5\end{array}$ \\
\hline M.26 & 85 & 15 & 75 & 75 & 25 & 100 \\
\hline M.9 & 85 & 15 & 75 & 75 & 25 & 90 \\
\hline B.396 & 85 & 15 & 75 & 75 & 25 & 100 \\
\hline P 67 & 85 & 15 & 75 & 75 & 25 & 100 \\
\hline P 22 & 60 & 40 & 75 & 50 & 50 & 75 \\
\hline
\end{tabular}

Bud development established according to Foster et al. (2003). $n=90$ buds per treatment. 
Among flowering promoters, the phytohormone with the highest accumulation was JA, which ranged from 150 to 438 $n g \mathrm{~g}^{-1} \mathrm{FW}$ in both varieties. Among the inhibitor phytohormones the highest accumulation was observed in IAA and $\mathrm{GA}_{7}$. IAA concentrations ranged from 36 to $270 \mathrm{ng} \mathrm{g}^{-1} \mathrm{FW}$, and from 76 to $310 \mathrm{ng} \mathrm{g}^{-1} \mathrm{FW}$, while $\mathrm{GA}_{7}$ concentrations ranged from 36 to $187 \mathrm{ng} \mathrm{g}^{-1} \mathrm{FW}$, and from 96 to $354 \mathrm{ng} \mathrm{g}^{-1} \mathrm{FW}$ in "Ligol" and "Auksis", respectively (Tables 2 and 3). Compared to "Auksis", such content range resulted in a higher ratio of promoter to inhibitor phytohormones in "Ligol" (Figure 1A). The significantly high content of all promoter and inhibitor phytohormones was observed in buds of semi-dwarfing M.26 rootstock with a crop load adjusted to 150 fruits per tree [M.26 (150)] in both varieties. Moreover, the accumulation of phytohormones and soluble sugars significantly increased with increasing crop load of "Auksis" on M.26, while an opposite tendency in soluble sugar accumulation in "Ligol" buds was observed (Tables 3-5). The lowest accumulation of all tested phytohormones was observed in buds of apple trees on dwarfing rootstocks M.9 and P 67, with crop load adjusted to 75 and 113, respectively in both varieties (Tables 3 and 4). The significant decrease in sugar contents in buds of "Ligol" was observed in the P 67 (crop load: 113 fruits per tree) treatment; however, M.9 (crop load: 150 fruits per tree) buds caused a significant decrease of sugars in "Auksis" (Table 5). Despite the content variation of phytohormones, the highest ratio of promoter to inhibitor phytohormones was in buds of "Ligol" on dwarfing P 67 rootstock with crop load adjusted to 113 , while semi-dwarfing M.26 rootstock with crop load adjusted to 150 resulted in the lowest ratio of promoter to inhibitor phytohormones. However, a significant increase in the level of promoter to inhibitor hormones was observed in buds of "Auksis" on dwarfing rootstock B.396 (crop load: 75 fruits per tree) and a decrease was observed on M.9 (crop load: 75 fruits per tree) treatment (Figure 1A). Semi-dwarfing M.26 rootstock led to a significant increase, while dwarfing P 67 rootstock resulted in a significant decrease in phytohormone accumulation, in both varieties (Tables 3 and 4). The opposite effect of M.26 and P 67 rootstocks on the ratio of promoters to inhibitors was detected in "Ligol" trees (Figure 1B). However, neither rootstock nor crop load significantly affected the ratio of promoter to inhibitor phytohormones in "Auksis". Although crop load did not significantly affect ABA accumulation, a load adjusted to 150 fruits per tree resulted in a significant increase in zeatin, JA, IAA, $\mathrm{GA}_{7}, \mathrm{GA}_{3}$, and $\mathrm{GA}_{1}$ levels in both varieties, in contrast to a load of 75 fruits per tree (Tables 3 and 4). No unique response was found for soluble sugar accumulation in apple tree buds (Table 5). M.26 rootstock produced a significant increase in glucose and sorbitol, while M.9 presented a significant increase in fructose in "Ligol" buds. A significant accumulation of all soluble sugars was detected in buds of "Auksis" on B.396 rootstock. A crop load of 75 fruits per tree significantly increased the content of glucose,

TABLE 3 | The effect of rootstock and crop load interaction on the accumulation of phytohormones in "Ligol" buds (ng g ${ }^{-1}$, FW).

\begin{tabular}{|c|c|c|c|c|c|c|c|}
\hline \multirow[t]{2}{*}{ Treatment } & \multicolumn{2}{|c|}{ Promoters } & \multicolumn{5}{|c|}{ Inhibitors } \\
\hline & Zeatin & JA & IAA & ABA & $\mathrm{GA}_{7}$ & $\mathrm{GA}_{3}$ & $\mathrm{GA}_{1}$ \\
\hline M.26 (75) & $9.04 c^{\star}$ & 278.2 de & 126.1 cde & $8.59 \mathrm{~d}$ & $108.7 \mathrm{e}$ & 18.8 e & $12.8 \mathrm{e}$ \\
\hline M.26 (113) & 10.94 b & 353.1 b & 198.1 b & 11.02 b & $148.1 \mathrm{c}$ & 30.2 b & $17.2 \mathrm{c}$ \\
\hline M.26 (150) & $12.83 \mathrm{a}$ & $428.0 \mathrm{a}$ & $270.1 \mathrm{a}$ & $13.45 \mathrm{a}$ & $187.4 \mathrm{a}$ & $41.5 \mathrm{a}$ & $21.6 \mathrm{ab}$ \\
\hline M.9 (75) & $3.83 \mathrm{~h}$ & $157.3 \mathrm{i}$ & $54.3 \mathrm{i}$ & 3.38 jkl & $67.9 \mathrm{i}$ & 8.99 h & $8.59 h$ \\
\hline M.9 (113) & $8.20 \mathrm{~cd}$ & 336.2 b & $105.5 \mathrm{fg}$ & $5.01 \mathrm{hi}$ & $129.2 \mathrm{~d}$ & $26.9 \mathrm{c}$ & $13.9 \mathrm{de}$ \\
\hline M.9 (150) & 6.64 ef & $246.6 \mathrm{fg}$ & $84.3 h$ & 2.821 & $77.2 \mathrm{~h}$ & $10.2 \mathrm{gh}$ & $9.74 \mathrm{gh}$ \\
\hline B.396 (75) & 6.56 ef & $330.7 \mathrm{bc}$ & $104.9 \mathrm{fg}$ & $8.01 \mathrm{de}$ & $94.2 \mathrm{f}$ & $18.8 \mathrm{e}$ & $15.8 \mathrm{~cd}$ \\
\hline B.396 (113) & $5.51 \mathrm{fg}$ & 261.5 ef & 110.8 efg & 7.12 ef & $112.3 \mathrm{e}$ & $21.6 \mathrm{~d}$ & $16.6 \mathrm{c}$ \\
\hline B.396 (150) & $8.77 \mathrm{c}$ & 351.8 b & $135.8 \mathrm{~cd}$ & $9.78 \mathrm{c}$ & $164.4 \mathrm{~b}$ & $19.1 \mathrm{e}$ & $22.5 \mathrm{a}$ \\
\hline P 67 (75) & $5.08 \mathrm{~g}$ & $179.2 \mathrm{i}$ & 48.4 ij & $5.49 \mathrm{gh}$ & $86.0 \mathrm{~g}$ & $15.1 \mathrm{f}$ & $11.9 \mathrm{efg}$ \\
\hline P 67 (113) & $3.72 \mathrm{~h}$ & $161.8 \mathrm{i}$ & $35.8 j$ & $3.20 \mathrm{kl}$ & $36.0 \mathrm{j}$ & $4.96 i$ & $8.95 h$ \\
\hline P 67 (150) & $7.04 \mathrm{e}$ & $302.6 \mathrm{~cd}$ & 119.9 def & 3.50 jkl & $85.2 \mathrm{gh}$ & 18.4 e & $10.4 \mathrm{fgh}$ \\
\hline P 22 (75) & $7.38 \mathrm{de}$ & $330.6 \mathrm{bc}$ & $137.8 \mathrm{c}$ & $6.22 \mathrm{fg}$ & 89.1 fg & 26.2 c & $19.5 b$ \\
\hline P 22 (113) & 7.20 de & $222.7 \mathrm{gh}$ & 113.9 efg & 4.34 ij & $88.3 \mathrm{fg}$ & $11.2 \mathrm{gh}$ & 12.4 ef \\
\hline P 22 (150) & 7.19 de & $212.4 \mathrm{~h}$ & $101.5 \mathrm{~g}$ & 4.17 ijk & $88.3 \mathrm{fg}$ & $11.6 \mathrm{~g}$ & $11.8 \mathrm{efg}$ \\
\hline \multicolumn{8}{|c|}{ Effect of rootstock } \\
\hline M.26 & $10.94 \mathrm{a}$ & $353.1 \mathrm{a}$ & $198.1 \mathrm{a}$ & $11.02 \mathrm{a}$ & $148.1 \mathrm{a}$ & $30.2 \mathrm{a}$ & $17.2 \mathrm{~b}$ \\
\hline М.9 & 6.22 c & 246.7 c & $81.4 \mathrm{c}$ & $3.74 \mathrm{~d}$ & $91.4 \mathrm{C}$ & $15.4 \mathrm{c}$ & $10.7 \mathrm{~d}$ \\
\hline B.396 & 6.95 b & $314.7 \mathrm{~b}$ & $117.2 \mathrm{~b}$ & $8.30 \mathrm{~b}$ & $123.7 \mathrm{~b}$ & 19.8 b & $18.3 \mathrm{a}$ \\
\hline P 67 & $5.28 d$ & $214.5 d$ & $68.0 \mathrm{~d}$ & $4.06 \mathrm{~d}$ & $69.1 \mathrm{~d}$ & $12.8 d$ & $10.4 \mathrm{~d}$ \\
\hline P 22 & 7.26 b & 255.2 c & $117.7 \mathrm{~b}$ & $4.91 \mathrm{C}$ & 88.6 c & $16.3 \mathrm{c}$ & $14.6 \mathrm{c}$ \\
\hline \multicolumn{8}{|c|}{ Effect of crop load } \\
\hline 75 & $6.38 \mathrm{c}$ & 255.2 c & $94.3 \mathrm{c}$ & $6.34 \mathrm{a}$ & 89.2 c & $17.6 \mathrm{c}$ & $13.7 b$ \\
\hline 113 & $7.11 \mathrm{~b}$ & 267.0 b & $112.8 \mathrm{~b}$ & $6.14 \mathrm{a}$ & $102.8 b$ & 19.1 b & $13.8 \mathrm{~b}$ \\
\hline 150 & 8.49 a & $308.3 \mathrm{a}$ & $142.3 \mathrm{a}$ & $6.74 \mathrm{a}$ & $120.5 \mathrm{a}$ & $20.1 \mathrm{a}$ & $15.2 \mathrm{a}$ \\
\hline
\end{tabular}

*The different letters on the same column indicate significant differences between treatments, rootstock and crop load separately. The analysis was conducted with all data resulting from 9 trees of "Ligol" apple tree grafted on M.26, M.9, B.396, P 67, and P 22, with crop-load adjusted to 75, 113, and 150 fruits per tree. The data were processed using analysis of variance (ANOVA), the Turkey (HSD) multiple range test at the confidence level $p=0.05$.

$J A$, jasmonic acid; IAA, indolyl-3 acetic acid; $A B A$, abscisic acid; $G A_{7}, G A_{3}, G A_{1}$, gibberellins. 



FIGURE 1 | The effect of rootstock (B) and crop load (C) interaction (A) on the ratio of flowering promoters to inhibitors phytohormones in "Ligol" and "Auksis" buds. "The different letters on bars of same cultivar indicate significant differences. The analysis was conducted with all data resulting from 9 trees of "Ligol" and "Auksis" apple tree grafted on M.26, M.9, B.396, P 67, and P 22, with crop-load adjusted to 75, 113, and 150 fruits per tree. The data were processed using analysis of variance (ANOVA), the Turkey (HSD) multiple range test at the confidence level $p=0.05$. Promoters - zeatin and jasmonic acid; Inhibitors - indolyl-3 acetic acid; abscisic acid; gibberellins $\left(\mathrm{GA}_{7}, \mathrm{GA}_{3}, \mathrm{GA}_{1}\right)$.

fructose, and sorbitol in "Ligol", while in "Auksis", such increase was the result of crop load adjusted to 113 fruits per tree. Due to increased levels of inhibitor phytohormones, both rootstock and crop load produced either a strong or very strong negative correlation between the ratio of promoter to inhibitor phytohormones and analyzed phytohormones, while a positive correlation was found between the ratio of promoter to inhibitor phytohormones and fructose in "Ligol" (Figures 2A, C; Table S1). The correlation between the ratio of promoter to inhibitor phytohormones and sugars in buds of "Auksis" was not significant. In contrast to rootstock, crop load resulted in a strong correlation between the ratio of promoter to inhibitor phytohormones and zeatin, JA, IAA, ABA, $\mathrm{GA}_{7}, \mathrm{GA}_{3}$, and $\mathrm{GA}_{1}$ in "Auksis" (Figures 2C, D; Table S2).

PCA results show the average coordinates of individual phytohormones (zeatin, JA, IAA, $\mathrm{ABA}, \mathrm{GA}_{7}, \mathrm{GA}_{3}$, and $\mathrm{GA}_{1}$ ), soluble sugars (glucose, fructose, and sorbitol), ratio of promoter to inhibitor phytohormones, and return bloom, in response to rootstocks with different growth vigor, and crop load. The first two factors (F1 vs. F2) of the PCA, as shown in the correlation circle (Figure 2) and scatterplot (Figure 3), explained $84.32 \%$ and $82.44 \%$ of the total data variance of rootstocks (Figures 3A, C), as well as $94.57 \%$ and $84.86 \%$ of that of crop load (Figures 3B, D) in "Ligol" and "Auksis", respectively. F1 explained $11 \%-23 \%$ of the total variance, whereas F2 explained $72.57 \%$ and $61.80 \%$ (effect of rootstock on "Ligol" and "Auksis", respectively), as well as $71.90 \%$ and $61.49 \%$ (effect of crop load for "Ligol" and "Auksis", respectively) of the total variability. Therefore, F2 described the disparity among rootstock and crop load effects. To summarize all the effects observed in the PCA scatter plot, the effect of the semi-dwarfing M.26 rootstock was significantly different from that of the dwarfing M.9 and P 67 rootstocks, in both varieties (Figures $\mathbf{3 A}, \mathbf{C}$ ). The super-dwarfing P 22 rootstock also presented a similar metabolic response of phytohormones and sugars to dwarfing rootstocks. The most intensive crop load (150 fruits per apple tree) produced a significantly different response to less intensive crop loads (113 and 75) in both varieties (Figures 3B, D).

The AHC analysis was used to divide the rootstock and crop load into groups of increasing dissimilarity. Three clusters were identified in both "Ligol" (Figure 4A) and "Auksis" (Figure 4B) samples. This division correspond to apple rootstocks grouped according to vigor and crop load in cluster 2 [M.26(113), M.26 (150), B.396(150)] and cluster 3 [M.9(75), P 67(75), P 67(113)], but did not correspond in cluster 1 [M.26(75), M.9(113), B.396 (75), P 67(150), P 22(75)] in both varieties. Rootstocks M.9 and P 22 with crop load of 150 fruits per tree and rootstocks B.396 and P 22 with crop load of 113 fruits per tree belonged to cluster 3 in "Ligol" and to cluster 1 in "Auksis". With regards to bud phytohormones and sugars concentrations and return bloom four clusters were identified in "Ligol" (Figure 4A) and three clusters were identified in "Auksis" (Figure 4B). Group, which included M.9 and P 67 rootstocks with crop load of 75 fruits per tree and P 67 with crop load of 113 fruits per tree, was 
TABLE 4 | The effect of rootstock and crop load interaction on the accumulation of phytohormones in "Auksis" buds (ng g ${ }^{-1}$. FW).



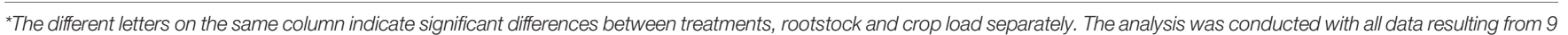


(ANOVA), the Turkey (HSD) multiple range test at the confidence level $p=0.05$.

$J A$, jasmonic acid; IAA, indolyl-3 acetic acid; $A B A$, abscisic acid; $\mathrm{GA}_{7}, \mathrm{GA}_{3}, \mathrm{GA}$, gibberellins.

characterized by low JA (cluster 2), $\mathrm{GA}_{7}$, and IAA (cluster 3) concentrations in both varieties. Other rootstock and crop load combinations distinguished in medium to high JA, $\mathrm{GA}_{7}$, and IAA concentrations. The return bloom was in the same cluster with IAA and $\mathrm{GA}_{7}(\mathrm{C} 3)$ in "Auksis" (Figure 4B), while in "Ligol" return bloom was in C4, but IAA and $\mathrm{GA}_{7}$ in $\mathrm{C} 3$ clusters (Figure 4A). Lower contents of inhibitory phytohormones (IAA and $\mathrm{GA}_{7}$ ) resulted in higher values of return bloom and vice versa. Other tested phytohormones and sugars were in $\mathrm{C} 1$ in both varieties. In contrast to "Auksis", during generative bud development in September (Table 1), semi dwarfing M.26 rootstock with crop load of 113 and 150 fruits per tree (cluster 2) distinguished in lower soluble sugars contents and low ratio of promoter to inhibitor phytohormones (Figure 4). Super dwarfing rootstock P 22 (cluster 1 and 3 for "Ligol", cluster 1 for "Auksis") showed low to medium contents of tested metabolites. There was no common tendency established for metabolite variation in dwarfing rootstocks M.9, B.396, and P 67.

\section{DISCUSSION}

Fruit tree species from the Rosaceae family are non-sensitive to changes in photoperiod and required mainly low nighttime temperatures to become floral (Hanninen and Tanino, 2011).
Fadón et al. (2020) suggested that winter dormancy induction is associated with leaf fall and refers to growth suppression imposed on particular organs by other tree structures (e.g., apical dominance) due to the production and/or action of inhibitory molecules. Hoover et al. (2004) and Mcartney et al. (2001) noticed that the duration of doming differs in different apple tree cultivars and the timing of floral commitment is not related either to the time of flowering, or to the time of fruit maturity of the cultivar the other cultivars. We found that apical meristems formed terminal floral meristems in both "Ligol" and "Auksis" cultivars (Table 2) in September. Therefore, with regards to morphological changes inside the buds, they became florally committed at the end of the growing season. Foster et al. (2003) found that the gynoecium and stamens were not distinguishable in Malus spp. during dormancy initiation, suspending flower development during early stages of apical meristems differentiation. Phytohormones such as ABA, GAs, IAA, CK, and possibly JA were implicated in direct or indirect regulation of different phase transitions during floral initiation processes (Charrier et al., 2011; Liu and Sherif, 2019) for the following year (Stephan et al., 2001). Compared to analyzed phytohormones, apple buds distinguished in the highest accumulation of JA, followed by $\mathrm{GA}_{7}$, and IAA in September (Tables 3 and 4). Moreover, a strong positive correlation between JA and inhibitor phytohormones was found (Figure 2; Tables S1 and S2), 
TABLE 5 | The effect of rootstock and crop load interaction on the accumulation of soluble sugars in "Ligol" and "Auksis" buds (mg g ${ }^{-1}$. FW).






variance (ANOVA), the Turkey (HSD) multiple range test at the confidence level $p=0.05$.

Glu, glucose; Fru, fructose; Sorb, sorbitol.

approved by AHC analysis (Figure 4) suggesting the important role of JA in apple bud developmental processes. ABA, a growth inhibitor and storage promoter, has been described as a key hormonal regulator in the floral initiation processes. In many plant species, ABA is antagonized by the growth promoter GA, which act as floral inhibitors (Wilkie et al., 2008; Fadón et al., 2020). However, in concurrence with Peace et al. (2019), ABA and GAs in apple trees acted synergistically, a positive correlation was found between ABA and GAs in both varieties (Figure 2; Tables S1 and S2; Figure 4). At the early stage of apical meristem differentiation, GAs may activate the metabolic pathways, even though a decline in GA (especially $\mathrm{GA}_{3}$ and $\mathrm{GA}_{4}$ ) levels induces growth cessation and bud set. $\mathrm{GA}_{4}$ treatment led to the enhancement of several energy metabolism pathways, including those associated with sugar metabolism (Zhuang et al., 2015). In contrast to rootstock, crop load resulted in negative correlations between GAs $\left(\mathrm{GA}_{1}, \mathrm{GA}_{3}\right.$, and $\left.\mathrm{GA}_{7}\right)$ and soluble sugars (glucose and sorbitol) (Figure 2; Tables S1 and S2). Nonstructural carbohydrate dynamics have often been assigned as long-distance sugar signaling pathway in developmental changes in shoot apical meristems (Moghaddam and Van den Ende, 2013). Fadón et al. (2020) stated that trees exhibit strong fluctuations in early shoot apical meristem developmental stages in the rates at which soluble sugars (i.e., glucose, fructose, and sorbitol) and starch are synthesized and degraded. In late autumn and during winter, carbohydrate synthesis declines progressively until leaf fall, with nonstructural carbohydrates acting as reserve molecules, and possibly supporting future growth. Xylem transport is progressively limited (by IAA and CK antagonistic action in the shoot apical meristem) in autumn, because leaf senescence and leaf fall cause a progressive reduction in transpiration (Aloni et al., 2010; Müller and Leyser, 2011). Li et al. (2012) indicated that apple is unique in terms of sugar metabolism and accumulation, as almost all sorbitol and a half of sucrose are converted to hexoses by invertase.

Aloni et al. (2010) suggested that invigorating properties of the rootstocks induced a higher growth rate in the scion, possibly by increasing the supply of CK to the shoot and decreasing that of IAA. In addition, rootstocks with dwarfing characteristics similar to those of M.9 and MM.106 indicated that altered auxin transport was also likely to be involved, with dwarfing rootstocks exhibiting a reduced capacity for polar auxin transport (Else et al., 2018). Compared to dwarfing rootstocks, the semi-dwarfing M.26 rootstock induced the accumulation of zeatin and IAA in buds of both apple tree varieties (Tables 3 and 4). Baron et al. (2019) found that dwarfing apple rootstocks contained lower amounts of plant growth promoter phytohormones, but higher amounts of inhibitor phytohormones, than vigorous rootstocks of the same species, with high ABA levels present in dwarfing rootstock stems. We found that buds of "Ligol" on dwarfing rootstocks accumulated larger amounts of flowering 



FIGURE 2 | Correlation circle of phytohormones, soluble sugars and return bloom depending on rootstock (A, C) and on crop load (B, D) in "Ligol" and "Auksis" apple trees respectively. The analysis was conducted with all data resulting from 9 trees of "Ligol" and "Auksis" apple trees grafted on M.26, M.9, B.396, P 67, and P 22, with crop-load adjusted to 75, 113, and 150 fruits per tree. JA, jasmonic acid; IAA, indolyl-3 acetic acid; ABA, abscisic acid; $\mathrm{GA}_{7}, \mathrm{GA}_{3}$, GA 1 , gibberellins; Glu, glucose; Fru, fructose; Sorb, sorbitol.

promoter phytohormones (zeatin and JA) compared to the semidwarfing M.26 rootstock (Figure 1B), and that buds of dwarfing rootstocks presented lower ABA levels in both varieties (Tables 3 and 4). Though dwarfing rootstocks of apple plants contain large amounts of ABA in their xylem (Lordan et al., 2017; Else et al., 2018), ABA accumulation in buds was induced by the more vigorous M.26 rootstock (Tables 3 and 4). While ABA can limit extension growth by suppressing $\mathrm{GA}_{1}$ accumulation (Benschop et al., 2005), it is not known whether rootstock-sourced ABA and scion-derived GAs interact to regulate shoot extension in grafted scions. Van Hooijdonk et al. (2010) determined that exogenously applied $\mathrm{GA}_{4+7}$ primarily reduced the proportion of primary and secondary shoots that presented early terminated growth, thereby increasing the final length and node number of "Royal Gala" shoots on M.9. An endogenous signaling mechanism is proposed here, whereby dwarfing rootstocks reduce the basipetal transport of IAA to the root, consequently decreasing the amount of root-produced
CK and GA transported to the scion. However, no evidence was found to suggest that the dwarfing capacity of M.9 rootstocks could be attributed to a reduced supply of CKs from the rootstock to the scion (Else et al., 2018). Compared to the semi-dwarfing M.26 rootstock, dwarfing rootstocks (M.9, B.396, P 67, and P 22) resulted in a decrease of zeatin, JA, IAA ABA, and GAs except for an increase of $\mathrm{GA}_{1}$ in "Ligol" and an increase of $\mathrm{GA}_{7}$ in "Auksis" on B.396 (Tables 2 and 3). This could explain why the return bloom on B.396 rootstock was markedly the lowest for "Auksis" and average for both cultivars (Table 1). However, it should be noted that the accumulation, and especially the ratio, of these phytohormones was highly dependent on the developmental stage of apical meristems.

IAA and ABA can act as control factors in the ripening process, as sharp increases in the accumulation of both hormones occurred, and were followed by, the corresponding fruit quality indices. A significant increase of IAA concentration in the leaves of "Ligol" trees grafted on M.9 rootstock lead to slower ripening, 
A



C

'Ligol' (axes F1 and F2: $94.57 \%$ )



B



D 'Auksis' (axes F1 and F2: $84.86 \%$ )



FIGURE 3 | The PCA scatterplot, indicating distinct differences in phytohormones, soluble sugars and return bloom depending on rootstock (A, C) and crop load (B, D) in "Ligol" and "Auksis" apple trees respectively. The analysis was conducted with all data resulting from 9 trees of "Ligol" and "Auksis" apple trees grafted on M.26, M.9, B.396, P 67, and P 22, with crop-load adjusted to 75, 113, and 150 fruits per tree.


FIGURE 4 | Agglomerative hierarchical cluster (AHC) analysis in "Ligol" (A) and "Auksis" (B). Phytohormones, soluble sugars and return bloom grouped by similarities in concentration mean and intensity values. The analysis was conducted with all data resulting from 9 trees of "Ligol" and "Auksis" apple trees grafted on M.26, M.9, B.396, P 67 , and P 22, with crop-load adjusted to 75,113 , and 150 fruits per tree. 
while a significant increase of $\mathrm{ABA}$ concentration, together with the highest ripening rate, were detected in "Ligol" apple trees with the lowest crop load (Samuoliene et al., 2019).

Foster et al. (2017) found that compared to the dwarfing M.27 and the vigorous M.793 rootstocks, fructose and glucose concentrations were significantly lower in stems (above and below the graft junction) and roots tissues of the "Royal Gala" M.9 trees. This suggested that the low concentration of glucose, fructose, and myo-inositol in trees with M.9 rootstock would have a significant effect on the physiology of both rootstock and scion. In comparison to semi-dwarfing or super-dwarfing rootstocks, a similar decrease in soluble sugars in "Ligol" leaves from dwarfing P 67 and B.396 rootstocks was reported by Samuolienè et al. (2016). In agreement with previously obtained data, the significant decrease in fructose, glucose, and sorbitol levels in "Ligol" buds was also found in less vigorous rootstocks, except for a significantly higher fructose concentration in buds of "Ligol" trees on M.9 rootstock. A significant increase in soluble sugar content in buds of "Auksis" on dwarfing B.396 rootstock was observed, while no difference in glucose accumulation was observed between the semi-dwarfing M.26, dwarfing B.396, and super-dwarfing P 22 rootstocks (Table 5). The differences in soluble sugar accumulation in buds produced by these rootstocks may be related to the different periods of time required for fruit ripening between "Ligol" and "Auksis". Guitton et al. (2016) suggested that competition for carbohydrates between the developing fruit and nearby apical buds lead to local carbon depletion and reduced cellular activity in the vegetative meristems, thus blocking the onset of floral development. While all sugars are transported via the sap to the buds just before budburst, carbohydrate dynamics are restricted to the bud tissues during early stages of apical meristems differentiation. Therefore, soluble sugar levels were increased in (Signorelli et al., 2018). Rootstock-dependent positive correlations between glucose and IAA, as well as between glucose and ABA (Figure 2; Tables S1 and S2) indicated that glucose, IAA, and $\mathrm{ABA}$ act synergistically and that apple tree flower induction was influenced by sugar metabolism, as well as auxin and ABA signaling pathways. However, crop load-dependent correlations between glucose, sorbitol, and phytohormones were not significant in both varieties.

Tromp (2000), in his review on the effect of thinning on return bloom, indicated that the flower formation process is not sufficiently understood, especially in the early phases. Return bloom generally decreases as crop load increases (Serra et al., 2016). Marini et al. (2013) found that flower density was negatively correlated with the previous season's crop load and that the interaction between rootstock and crop load was not established. Our data confirmed a negative correlation between crop load and return bloom (Table 1) of both tested cultivars, based on the averaged data obtained from all rootstocks. The highest crop load significantly suppressed return bloom and supported the findings of Embree et al. (2007), where biennial bearing was observed in "Honeycrisp" apple trees thinned to 150 blossom clusters. However, the effect of rootstock on the suppression of return bloom when comparing the lowest and highest crop levels was different for both cultivars. "Ligol" on M.26 rootstock recorded a decrease in flowering of approximately $90 \%$, while a decrease of approximately $75 \%$ was recorded on M.9 and P 22 rootstocks. Meanwhile, the highest decrease in flowering (38\%) was recorded for "Auksis" on M.9 rootstock. A very stable return bloom of "Auksis" was produced on B.396 and P 67 rootstocks, where differences between contrasting levels were only $5 \%$ and $11 \%$ respectively. This, however, cannot be explained by the ratio of flowering promoters to inhibitor phytohormones (Figure 1), indicating that bearing stability is more dependent on these rootstocks, but not on the crop load. Rootstock-scion interactions on return bloom were detected in our previous study (Kviklys et al., 2016) and in the study of 48 apple rootstocks, where several Geneva rootstocks were distinguished by low alternate bearing (Reig et al., 2018).

Return bloom of "Ligol" significantly correlated with the ratio of promoter and inhibitor hormones, while no such correlation was established for "Auksis" (Tables S1 and S2). The AHC analysis showed that return bloom was more dependent on IAA, GA 7 and JA, rather than on other phytohormones or sugars in both varieties. Generally, higher correlations between phytohormones, soluble sugars, and return bloom were established, evaluating the effect of crop load, but not that of rootstocks. Return bloom of both cultivars on all rootstocks negatively correlated with the amount of sorbitol in buds, and additionally with the amount of fructose in the case of "Auksis".

The PCA scatter plot on the metabolic response of phytohormones and sugars indicated that the effect of the semi-dwarfing M.26 rootstock was significantly different from that of the dwarfing M.9 and P 67, as well as of the superdwarfing P 22 rootstocks in both varieties. The most intensive crop load (150 fruits per apple tree) produced a significantly different response compared to less intensive crop loads (113 and 75) in both varieties. In contrast to soluble sugar accumulation, increased crop load resulted in increased levels of phytohormones, but did not affect $\mathrm{ABA}$ accumulation.

Dwarfing rootstocks M.9, B.396, and P 67, as well as the super-dwarf $\mathrm{P} 22$ resulted in altered accumulation of promoter phytohormones, while the more vigorous semi-dwarfing M.26 rootstock induced a higher content of glucose in "Ligol" buds, of glucose and sorbitol in "Auksis" buds, and of inhibitory phytohormones, by increasing the levels of IAA, ABA, and GAs. Therefore, soluble sugars, especially glucose, and hormonal pathways were interconnected and acted together to control flower induction, while being both rootstock- and crop load-dependent.

Apple return bloom was dependent both on rootstock and crop load. Interactions between rootstocks and cultivars were established: M.9 rootstock determined the highest return bloom for "Auksis", and P 67 rootstock for "Ligol". The lowest return bloom was recorded on the super dwarfing P 22 rootstock in "Ligol", and on the dwarfing B.396 in "Auksis". Comparing the effect of rootstock on return bloom under different crop load 
levels showed that the most significant decrease in return bloom resulted from the highest crop load in "Auksis" grafted on M.9 and P 22 rootstocks, and in "Ligol" grafted on P 22 rootstock.

\section{DATA AVAILABILITY STATEMENT}

All datasets presented in this study are included in the article/ Supplementary Material.

\section{AUTHOR CONTRIBUTIONS}

DK-trial setup, field trials, data analysis, and writing of the manuscript. GS-chromatographic analysis, data analysis, and

\section{REFERENCES}

Albacete, A., Martínez-Andújar, C., Martínez-Pérez, A., Thompson, A. J., Dodd, I. C., and Pérez-Alfocea, F. (2015). Unravelling rootstock $\times$ scion interactions to improve food security. J. Exp. Bot. 66 (8), 2211-2226. doi: 10.1093/jxb/erv027

Aloni, B., Cohen, R., Karni, L., Aktas, H., and Edelstein, M. (2010). Hormonal signaling in rootstock-scion interactions. Sci. Hortic. 127, 119-126. doi: $10.1016 /$ j.scienta.2010.09.003

Autio, W. R. (2001). Rootstock and scion interact to affect apple tree performance: results from the $1990 \mathrm{NC}-140$ cultivar/rootstock trial. Acta Hortic. 557, 41-46. doi: 10.17660/ActaHortic.2001.557.3

Baron, D., Amaro, A. C. E., Pina, A., and Ferreira, G. (2019). An overview of grafting re-establishment in woody fruit species. Sci. Hortic. 243, 84-91. doi: 10.1016/j.scienta.2018.08.012

Benschop, J. J., Jackson, M. B., Guhl, K., Vreeburg, R. A. M., Croker, S. J., Peeters, A. J. M., et al. (2005). Contrasting interactions between ethylene and abscisic acid in Rumex species differing in submergence tolerance. Plant J. 44, 756-768. doi: 10.1111/j.1365-313X.2005.02563.x

Charrier, G., Bonhomme, M., Lacointe, A., and Améglio, T. (2011). Are budburst dates, dormancy and cold acclimation in walnut trees (Juglans regia L.) under mainly genotypic or environmental control? Int. J. Biometeorol. 55, 763-774. doi: 10.1007/s00484-011-0470-1

Cheng, W.-H., Endo, A., Zhou, L., Penney, J., Chen, H.-C., Arroyo, A., et al. (2002). A unique short-chain dehydrogenase/reductase in Arabidopsis glucose signaling and abscisic acid biosynthesis and functions. Plant Cell 14, 27232743. doi: $10.1105 /$ tpc.006494

Denardi, F., Kvitschal, M., and Hawerroth, M. (2018). Yield performance of apple rootstocks of the Geneva series on replanting soil. Pesq. Agropec. Bras. 53 (8), 924-933. doi: 10.1590/s0100-204x2018000800007

Dennis, F. G. J. R. (2000). The history of fruit thinning. Plant Growth Reg. 31, 1-16. doi: 10.1023/A:1006330009160

Else, M. A., Taylor, J. M., Young, S., and Atkinson, C. J. (2018). The effect of the graft union on hormonal and ionic signalling between rootstocks and scions of grafted apple (Malus pumila L. Mill.). Env. Exp. Bot. 156, 325-336. doi: 10.1016/j.envexpbot.2018.07.013

Embree, C., Myra, M., Nichols, D., and Wright, A. (2007). Effect of Blossom Density and Crop Load on Growth, Fruit Quality, and Return Bloom in 'Honeycrisp' Apple. Hort. Sci. 42 (7), 1622-1625. doi: 10.21273/ HORTSCI.42.7.1622

Eveland, A. L., and Jackson, D. P. (2012). Sugars, signalling, and plant development. J. Exp. Bot. 63, 3367-3377. doi: 10.1093/jxb/err379

Fadón, E., Fernandez, E., Behn, H., and Luedeling, E. (2020). A conceptual framework for winter dormancy in deciduous trees. Agronomy 10:241. doi: 10.3390/agronomy10020241

Foster, T., Hohnston, R., and Seleznyova, A. (2003). A morphological and quantitative characterization of early floral development in apple (Malus $\mathrm{x}$ domestica Borkh.). Ann. Bot. 92, 199-206. doi: 10.1093/aob/mcg120 writing of the manuscript. All authors contributed to the article and approved the submitted version.

\section{FUNDING}

This research was funded by a grant (No. MIP-036-2014) from the Research Council of Lithuania.

\section{SUPPLEMENTARY MATERIAL}

The Supplementary Material for this article can be found online at: https://www.frontiersin.org/articles/10.3389/fpls.2020.01213/ full\#supplementary-material

Foster, T., McAtee, P. A., Waite, C. N., Boldingh, H. L., and McGhie, T. K. (2017). Apple dwarfing rootstocks exhibit an imbalance in carbohydrate allocation and reduced cell growth and metabolism. Hortic. Res. 4, 17009. doi: 10.1038/ hortres.2017.9

Guitton, B., Kelner, J. J., Celton, J. M., Sabau, X., Renou, J. P., Chagné, D., et al. (2016). Analysis of transcripts differentially expressed between fruited and deflowered 'Gala' adult trees: a contribution to biennial bearing understanding in apple. BMC Plant Biol. 16, 1-22. doi: 10.1186/s12870-016-0739-y

Hanninen, H., and Tanino, K. (2011). Tree seasonality in a warming climate. Trends Plant Sci. 16, 412-416. doi: 10.1016/j.tplants.2011.05.001

Harrison, N., Barber-Perez, N., Pennington, B., Cascant-Lopez, E., and Gregory, P. J. (2016). Root system architecture in reciprocal grafts of apple rootstock-scion combinations. Acta Hortic. 1130, 409-414. doi: 10.17660/ActaHortic. 2016.1130.61

Hirst, P. M., Autio, W. R., Barden, J. A., Brown, G. R., Crassweller, R. M., Domoto, P. A., et al. (2001). Performance of Trees in the NC-140 Apple Cultivar/ Rootstock Planting: Additional Cultivars and Rootstocks. J. Am. Pom. Soc. (APS) 55, 178-184.

Hoover, E., De Silva, N., Mcartney, S., and Hirst, P. (2004). Bud development and floral morphogenesis in four apple cultivars. J. Hortic. Sci. Biotechnol. 79 (6), 981-984. doi: 10.1080/14620316.2004.11511877

Hornitschek, P., Kohnen, M. V., Lorrain, S., Rougemont, J., Ljung, K., LópezVidriero, I., et al. (2012). Phytochrome interacting factors 4 and 5 control seedling growth in changing light conditions by directly controlling auxin signaling. Plant J. 71, 699-711. doi: 10.1111/j.1365-313X.2012.05033.x

Jensen, P., Makalowska, I., Altman, N., Fazio, G., Praul, C., Maximova, S., et al. (2010). Rootstock-regulated gene expression patterns in apple tree scions. Tree Gen. Genom. 6, 57-72. doi: 10.1007/s11295-009-0228-7

Kittikorn, M., Shiraishi, N., Okawa, K., Ohara, H., Yokoyama, M., Ifuku, O., et al. (2010). Effect of fruit load on 9,10-ketoloctadecadienoic acid (KODA), GA and jasmonic cid concentrations in apple buds. Sci. Hortic. 124, 225-230. doi: 10.1016/j.scienta.2010.01.008

Kviklys, D., Kvikliené, N., Bite, A., Lepsis, J., Univer, T., Univer, N., et al. (2012). Baltic fruit rootstock studies: evaluation of 12 apple rootstocks in North-East Europe. Hortic. Sci. 39 (1), 1-7. doi: 10.17221/29/2011-HORTSCI

Kviklys, D., Kviklienè, N., Bielicki, P., Bite, A., Lepsis, J., Univer, T., et al. (2013). Baltic fruit rootstock studies: evaluation of apple (Malus domestica Borkh.) new rootstocks. Zemdirbyste-Agric. 100 (4), 441-446. doi: 10.13080/za.2013.100.056

Kviklys, D., Liaudanskas, M., Janulis, V., Viškelis, P., Rubinskienė, M., Lanauskas, J., et al. (2014). Rootstock genotype determines phenol content in apple fruits. Plant Soil Envir. 60 (5), 234-240. doi: 10.17221/71/2014-PSE

Kviklys, D., Čeidaitè, A., Lanauskas, J., Uselis, N., and Samuolienè, G. (2016). The effect of rootstock on apple tree bearing stability in a cooler climate. Agric. Food Sci. 25 (1), 81-88. doi: 10.23986/afsci.53381

Kviklys, D., Liaudanskas, M., Viškelis, J., Buskienė, L., Lanauskas, J., Uselis, N., et al. (2017). Composition and concentration of phenolic compounds of 
'Auksis' apple grown on various rootstocks. Proc. Latvian Acad. Sci. Section B 71(3) (3), 144-149. doi: 10.1515/prolas-2017-0025

Li, T. H., and Li, S. H. (2007). Enzymatic regulation of sorbitol metabolism in micropropagated apple plants in response to water stress. Eur. J. Hortic. Sci. $72,12-19$

Li, M., Feng, F., and Cheng, L. (2012). Expression patterns of genes involved in sugar metabolism and accumulation during apple fruit development. PloS One 7, e33055. doi: 10.1371/journal.pone.0033055

Li, J., Xu, Y., Niu, Q., He, L., Teng, Y., and Bai, S. (2018). Abscisic acid (ABA) promotes the induction and maintenance of pear (Pyrus pyrifolia white pear group) flower bud endodormancy. Int. J. Mol. Sci. 19 (1), 310. doi: 10.3390/ ijms19010310

Liu, J., and Sherif, S. M. (2019). Hormonal orchestration of bud dormancy cycle in deciduous woody perennials. Front. Plant Sci. 10:1136:1136. doi: 10.3389/ fpls.2019.01136

Ljung, K., Nemhauser, J. L., and Perata, P. (2015). New mechanistic links between sugar and hormone signalling networks. Curr. Opin. Plant Biol. 25, 130-137. doi: $10.1016 /$ j.pbi.2015.05.022

Lordan, J., Fazio, G., Francescatto, P., and Robinson, T. (2017). Effects of apple (Malus $\mathrm{x}$ domestica) rootstocks on scion performance and hormone concentration. Sci. Hortic. 225, 96-105. doi: 10.1016/j.scienta.2017.06.050

Marini, R. P., Autio, W. R., Black, B., Cline, J., Cowgill, W. R., Crassweller, R. M., et al. (2013). Return bloom on 'Golden Delicious' apple trees as affected by previous season's crop density on three rootstocks at 11 locations. J. Am. Pom. Soc 67 (2), 73-79.

Mcartney, S. J., Hoover, M., Hirst, P. M., and Brooking, I. R. (2001). Seasonal variation in the onset and duration of flower development in 'Royal Gala' apple buds. J. Hortic. Sci. Biotechnol. 76 (5), 536-540. doi: 10.1080/14620316. 2001.11511406

Michalczuk, L. (2002). Indole-3-acetic acid level in wood, bark and cambial sap of apple rootstocks differing in growth vigour. Acta Physiol. Plant 24, 131-136. doi: $10.1007 / \mathrm{s} 11738-002-0002-\mathrm{z}$

Moghaddam, M. R. B., and Van den Ende, W. (2013). Sugars, the clock and transition to flowering. Front Plant Sci. 4:22. doi: 10.3389/fpls.2013.00022

Moore, B., Zhou, L., Rolland, F., Hall, Q., Cheng, W. H., Liu, Y. X., et al. (2003). Role of the Arabidopsis glucose sensor HXK1 in nutrient, light, and hormonal signaling. Science 300, 332-336. doi: 10.1126/science.1080585

Müller, D., and Leyser, O. (2011). Auxin, cytokinin and the control of shoot branching. Ann. Bot. 107, 1203-1212. doi: 10.1093/aob/mcr069

Nichols, D., Embree, C. G., and Fillmore, S. A. E. (2011). Dormant spur-wood pruning severity impacts on vegetative growth, blossom intensity and fruit weight of 'Honeycrisp' apple trees. Acta Hortic. 903, 681-687. doi: 10.17660/ ActaHortic.2011.903.94

Peace, C. P., Bianco, L., Troggio, M., van de Weg, E., Howard, N. P., Cornille, A., et al. (2019). Apple whole genome sequences: recent advances and new prospects. Hortic. Res. 6, 59. doi: 10.1038/s41438-019-0141-7

Pellerin, B. P., Buszard, D., Georgallas, A., and Nowakowski, R. J. (2012). A novel framework to consider endogenous hormonal control of apple tree flowering. Hort. Sci. 47 (5), 589-592. doi: 10.21273/HORTSCI.47.5.589

Procko, C., Crenshaw, C. M., Ljung, K., Noel, J. P., and Chory, J. (2014). Cotyledon-generated auxin is required for shade-induced hypocotyl growth in Brassica rapa. Plant Physiol. 165, 1285-1301. doi: 10.1104/pp.114.241844

Ramírrez, H., Benavides, A., Robledo, V., Alonso, R., and Gómez, J. (2004). Gibberellins and cytokinins related to fruit bud initiation in apple. Acta Hortic. 636, 409-413. doi: 10.17660/ActaHortic.2004.636.50

Reig, G., Lordan, J., Fazio, G., Grusak, M., Hoying, S., Cheng, L., et al. (2018). Horticultural performance and elemental nutrient concentrations on 'Fuji' grafted on apple rootstocks under New York State climatic conditions. Sci. Hortic. 227, 22-37. doi: 10.1016/j.scienta.2017.07.002

Samuolienè, G., Viškelienè, A., Sirtautas, R., and Kviklys, D. (2016). Relationships between apple tree rootstock, crop-load, plant nutritional status and yield. Sci. Hortic. 211, 167-173. doi: 10.1016/j.scienta.2016.08.027

Samuolienė, G., Viškelienė, A., Sirtautas, R., and Kviklys, D. (2019). Relationships among the rootstock and morphogenetic behaviour of apple tree in aspect for fruit quality. Acta Hortic. 1242, 115-122. doi: 10.17660/ActaHortic. 2019.1242.16

Serra, S., Leisso, R., Giordani, L., Kalcsits, L., and Musacchi, S. (2016). Crop Load Influences Fruit Quality, Nutritional Balance, and Return Bloom in 'Honeycrisp' Apple. Hort. Sci. 51 (3), 236-244. doi: 10.21273/HORTSCI. 51.3.236

Sharp, R. E., and LeNoble, M. E. (2002). ABA, ethylene and the control of shoot and root growth under water stress. J. Exp. Bot. 53, 33-37. doi: 10.1093/jexbot/ 53.366 .33

Signorelli, S., Agudelo-Romero, P., Meitha, K., Foyer, C. H., and Considine, M. J. (2018). Roles for light, energy, and oxygen in the fate of quiescent axillary buds. Plant Physiol. 176, 1171-1181. doi: 10.1104/pp.17.01479

Šimura, J., Antoniadi, I., Široká, J., Tarkowská, D., Strnad, M., Ljung, K., et al. (2018). Plant hormonomics: multiple phytohormone profiling by targeted metabolomics. Plant Physiol. 177, 476-489. doi: 10.1104/pp.18.00293

Sorce, C., Massai, R., Picciarelli, P., and Lorenzi, R. (2002). Hormonal relationships in xylem sap of grafted and ungrafted Prunus rootstock. Sci. Hortic. 93, 333342. doi: 10.1016/S0304-4238(01)00338-7

Stephan, M., Bangerth, F., and Schneider, G. (2001). Transport and metabolism of exogenously applied gibberellins to Malus domestica Borkh. cv. Jonagold. Plant Growth Regulat. 33, 77-85. doi: 10.1023/A:1017589530354

Tromp, J. (2000). Lower-bud formation in pome fruits as affected by fruit thinning. Plant Growth Reg. 31, 27-34. doi: 10.1023/A:1006342328724

Tworkoski, T., and Fazio, G. (2015). Effects of size-controlling apple rootstocks on growth, abscisic acid, and hydraulic conductivity of scion of different vigor. Int. J. Fruit Sci. 15 (4), 369-381. doi: 10.1080/15538362.2015.1009973

Tworkoski, T., and Fazio, G. (2016). Hormone and growth interactions of scions and size-controlling rootstocks of young apple trees. Plant Growth Regul. 78, 105-119. doi: 10.1007/s10725-015-0078-2

Tworkoski, T., and Miller, S. (2007). Rootstock effect on growth of apple scions with different growth habits. Sci. Hortic. 111 (4), 335-343. doi: 10.1016/ j.scienta.2006.10.034

Tylewicz, S., Petterle, A., Marttila, S., Miskolczi, P., Azeez, A., Singh, R. K., et al. (2018). Photoperiodic control of seasonal growth is mediated by ABA acting on cell-cell communication. Science 360 (6385), 212-215. doi: 10.1126/ science.aan 8576

Valiuškaitė, A., Uselis, N., Kviklys, D., Lanauskas, J., and Rasiukevičiūtè, N. (2017). Effect of sustainable plant protection and apple tree management on fruit quality and yield. Zemdirbyste-Agric. 104 (4), 353-358. doi: 10.13080/za.2017.104.045

Van Hooijdonk, B. M., Woolley, D. J., Warrington, I. J., and Tustin, D. S. (2010). Initial alteration of scion architecture by dwarfing apple rootstocks may involve shoot-root-shoot signalling by auxin, gibberellin, and cytokinin. J. Hortic. Sci. Biotechnol. 85, 59-65. doi: 10.1080/14620316.2010.11512631

Van Hooijdonk, B. M., Woolley, D. J., Warrington, I. J., and Tustin, D. S. (2011). Rootstocks modify scion architecture, endogenous hormones, and root growth of newly grafted 'Royal Gala' apple trees. J. Am. Soc Hortic. Sci. 136, 93-102. doi: 10.21273/JASHS.136.2.93

Wilkie, J. D., Sedgley, M., and Olesen, T. (2008). Regulation of floral initiation in horticultural trees. J. Exp. Bot. 59, 3215-3228. doi: 10.1093/jxb/ern188

Zhuang, W., Gao, Z., Wen, L., Huo, X., Cai, B., and Zhang, Z. (2015). Metabolic changes upon flower bud break in Japanese apricot are enhanced by exogenous GA4. Hortic. Res. 2, 15046. doi: 10.1038/hortres.2015.46

Conflict of Interest: The authors declare that the research was conducted in the absence of any commercial or financial relationships that could be construed as a potential conflict of interest.

Copyright (๑) 2020 Kviklys and Samuoliene. This is an open-access article distributed under the terms of the Creative Commons Attribution License (CC BY). The use, distribution or reproduction in other forums is permitted, provided the original author(s) and the copyright owner(s) are credited and that the original publication in this journal is cited, in accordance with accepted academic practice. No use, distribution or reproduction is permitted which does not comply with these terms. 